\title{
Hooch Tragedy in Majha Region of Punjab, India
}

\author{
Jaspinder P. Singh, ${ }^{1}$ Neha Chaudhary, ${ }^{2}$ Kuldip Kumarm ${ }^{3}$, Ashok Chanana ${ }^{4 *}$ \\ 1,2 Junior Resident, Department of Forensic Medicine \& Toxicology, GMC, Amritsar, Punjab, India \\ ${ }^{3}$ Associate Professor, Department of Forensic Medicine \& Toxicology, GMC, Amritsar \\ ${ }^{4}$ Professor \& Head, Department of Forensic Medicine \& Toxicology, GMC, Amritsar
}

\begin{abstract}
Due to rampant unemployment, the youth does not hesitate in engaging themselves in any work/job from where they can earn their livelihood. The underground trade of drug trafficking, drug peddling, and drug abuse is prevalent in this part of India for decades. This illicit trade affects the economy of the State and causes the physical, social, and mental degeneration of the persons consuming it. Recently about 150 people were affected after consuming illicit distilled spurious liquor in the Majha region of Punjab, and more than 100 people died due to it. Some of the cases were admitted to the hospital attached to Government Medical College, Amritsar. Out of these admitted cases, few of them succumbed to poisoning whose Forensic autopsies were conducted by the Department of Forensic Medicine \& Toxicology, GMC, Amritsar. The meticulous autopsy findings and the scientific interpretation of the analysis of the detected methanol alone or along with ethyl alcohol reported by the chemical examiner to Punjab government led to the establishment of a definite cause of death which helped the investigating agencies in apprehending the people involved in these criminal activities.
\end{abstract}

Keywords: Ethyl alcohol poisoning, Hooch Tragedy, Methyl alcohol poisoning, Spurious liquor.

Int J Eth Trauma Victimology (2021). DOI: 10.18099/ijetv.v7i01.9

\section{INTRODUCTION}

$\mathrm{M}$ ethanol, known as methyl alcohol or wood alcohol, is a chemical with the formula $\mathrm{CH}^{3} \mathrm{OH}$. Methanol is a light, volatile, colorless, flammable liquid with a distinctive odor very similar to, but slightly sweeter than, that of ethanol and produced as a by-product of the distillation of wood. It is used as antifreeze, solvent, fuel, and denaturant for ethanol. ${ }^{1}$

Accidental, mass killing, suicidal, methanol poisonings can occur both in developed and developing countries. ${ }^{2-4}$ Most acute methanol toxicity cases result from accidental ingestion. Methanol is not highly toxic, but it is metabolized to toxic metabolites like formaldehyde and formic acid, which cause metabolic acidosis, blindness, cardiovascular instability, and death. ${ }^{5-8}$ The minimal lethal dose of methanol in humans has been assumed to be 1 gram per $\mathrm{kg}$ of body weight. ${ }^{9}$ Methanol is fatal due to CNS depressant properties and effects of metabolites, ${ }^{10}$ and converted to formaldehyde which is converted to formic acid. ${ }^{11}$ Formic acid inhibits mitochondrial cytochrome c oxidase, causing the symptoms of hypoxia at the cellular level and causing metabolic acidosis. ${ }^{12}$

\section{Case Report}

The Hooch tragedy of the Majha region of Punjab claimed 125 lives in July-September 2020. The first deaths were reported in the village of Amritsar district on the night of $29^{\text {th }}$ July 2020. The death toll reached 121 on $7^{\text {th }}$ August 2020, which included 15 from Amritsar,92 from adjoining districts of Amritsar, i.e., Tarn Taran district, and 14 from Gurdaspur District. Some of the cases were admitted to the hospital attached to Government Medical College, Amritsar. The patients presented to the emergency department with pain abdomen, breathing difficulty, nausea, vomiting, sudden loss of vision. Almost all
Corresponding Author: Ashok Chanana, Department of Forensic Medicine and Toxicology, GMC, Amritsar, Punjab, India, e-mail: ashokchanna@yahoo.co.in

How to cite this article: Singh JP, Chaudhary N, KumarK, ChananaA. Hooch Tragedy in Majha Region of Punjab, India. Int J Eth Trauma Victimology. 2021;7(1):41-42.

Source of support: Nil

Conflict of interest: None

Received:03/06/2021;

Accepted: 12/06/2021;

Received in revised form: 10/06/2021; Published: 12/06/2021

the patients gave a history of ingestion of alcohol before the onset of symptoms. Forensic autopsies were conducted by the Dept. of Forensic Medicine \& Toxicology, GMC, Amritsar.

Postmortem finding favoring Cyanosis, froth at mouth and nostrils, neck veins prominently dilated and congested with dark-colored hypostasis.Generalized visceral Congestion was present. The lungs were heavy, voluminous, and edematous, with subpleural multiple Tardieu spots present. The stomach contained brownish-colored liquid with a spirituous odor (Figure 1). The viscera was preserved for qualitative and quantitative analysis of poison, if present and for HPE, and sent to the state Chemical Examiner, Govt of Punjab, Kharar, and Prof \& Head, Dept Pathology, Govt Medical College, Amritsar, Punjab, India.

The chemical examiner's report revealed ethyl and methyl alcohol in the viscera sent for Examination. The Blood Alcohol Concentration varied from $69 \mathrm{mg} / 100 \mathrm{~mL}$ to $195.5 \mathrm{mg} / 100 \mathrm{~mL}$. The cause of death was declared a failure of the brain's function due to severe acidosis resulting frommethyl alcohol poisoning.

Punjab Government also announced aINR 2 lakh compensation for each of the families of the deceased. The Punjab government suspended seven excise officials and 


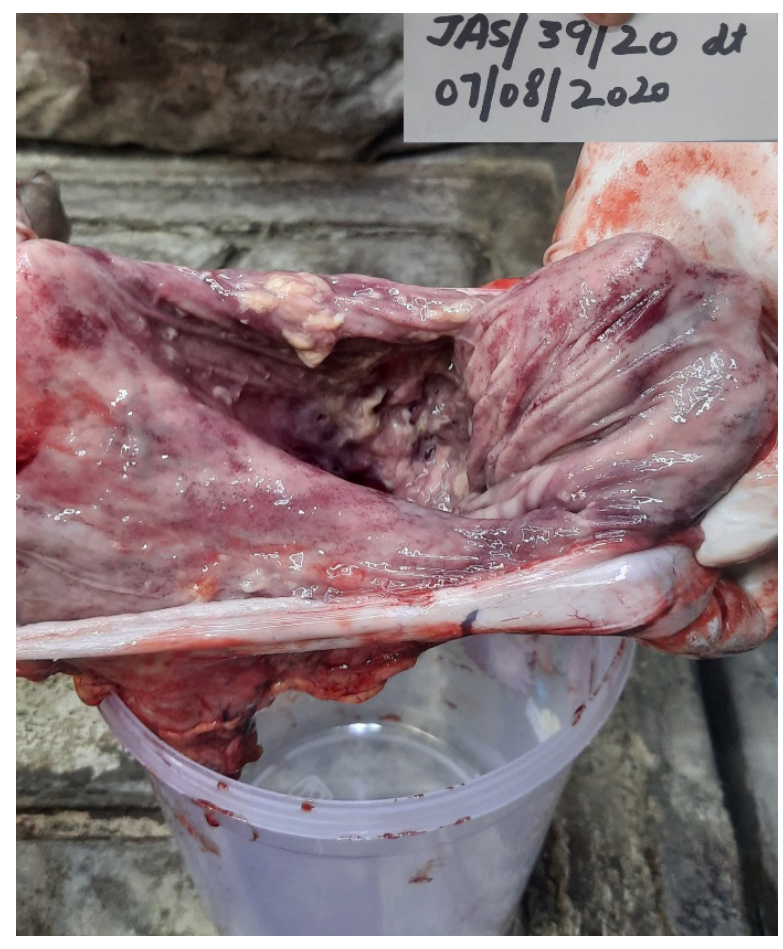

Figure 1: Showing submucosal haemorrhages on stomach mucosa.

six police officials. Police have managed to arrest a total of 37 people involved in the worst hooch tragedy Punjab has witnessed in three decades.

\section{Discussion}

Symptomatology noted in most of our cases was very similar to the reported series. ${ }^{13-16}$ However, the incidence of shock and unconsciousness was higher since this series refers only to the fatal cases.

Intoxication with methyl alcohol can occur with ingestion, inhalation of methanol vapor, or absorption through the skin. Methanol is oxidized to formaldehyde and then quickly oxidized to formic acid, both in vivo and in vitro. ${ }^{14}$ It is these metabolic products, which have a toxic action. The time interval between the ingestion of adulterated drink and presentation with symptomatology is due to time taken for methanol metabolism. The minimum time interval was around 12 hours in our series, whereas the maximum latent period was 120 hours. Bonnets et al. ${ }^{13}$ reported a latent period of 40-72 hours while Ravichandran et al., ${ }^{16}$ 4-60 hours. The death occurred in less than 48 hours after symptoms appeared in $75 \%$ of the cases. In $25 \%$ of cases, death was a late event, occurring 5 to 10 days after consuming the drink.

\section{REFERENCES}

1. Barceloux DG, Bond GR, Krenzelok EP, Cooper H, Vale JA. American Academy of Clinical Toxicology Ad Hoc Committee on the Treatment Guidelines for Methanol Poisoning. American Academy of Clinical Toxicology Practice Guidelines on the Treatment of Methanol Poisoning Journal of Toxicology. Clin Toxicol 2002; 40: 415-446.

2. Bonnets IL Jr, Cony FH, Mitchell GL Jr, Cooper MN. Acute methyl alcohol poisoning: a review based on experiences in an outbreak of 323 cases. Medicine 1953; 32:431-463.

3. Bucaretchi F, De Capitani EM, Madureira PR, Cesconetto DM, Lanaro R. Suicide attempt using pure methanol with hospitalization of the patient soon after ingestion: case report. Sao Paulo Med J 2009; 127: 108-110.

4. Epker JL, Bakker J. Accidental methanol ingestion: case report. BMC Emerg Med 2010; 10: 3.

5. Gender A, Manly H, Churchill D, Hollomby D. Hemodialysis for methanol intoxication. Amer J Med 1978; 64:749-758.

6. Jacobsen D, McMartin KE. Antidotes for methanol and ethylene glycol poisoning. J Toxicol Clin Toxicol 1997; 35: 127-143.

7. Kaplan K. Methyl alcohol poisoning. Amer J Med Sci 1962; 244:170-174.

8. Liesivuori J, Savolainen H. Methanol and formic acid toxicity: biochemical mechanisms. Pharmacol Toxicol 1991; 69: 157-163.

9. Martin-Amat G, McMartin KE, Hayreh SS, Hayreh MS, Tephly TR. Methanol poisoning: ocular toxicity produced by formate. Toxicol Appl Pharmacol 1978; 45: 201-208.

10. McMartin KE, Martin-Amat G, Noker PE, Tephly TR. Lack of a role for formaldehyde in methanol poisoning in the monkey. Biochem Pharmacol 1979; 28: 645-649.

11. Mowry JB, Spyker DA, Brooks DE, McMillan N, Schauben JL. 2014 Annual Report of the American Association of Poison Control Centers' National Poison Data System (NPDS): 32nd Annual Report. Clin Toxicol 2015; 53: 962-1147.

12. Paasma R, Hovda KE, Jacobsen D. Methanol Poisoning and Long Term Sequelae-a Six Years Follow-up after a Large Methanol Outbreak. BMC Clin Pharm 2009; 9: 5.

13. Ravichandran R, Dudani RA, Alongside AE, Chamber KP, Acharya VN. Methyl alcohol poisoning (experience of an outbreak in Bombay). J Postgrad Med 1974; 30:69-74.

14. Röe O. Species differences in methanol poisoning. Crit Rev Toxicol 1982; 10: 275-286.

15. Schep LJ, Slaughter RJ, Vale JA, Beasley DM. A seaman with blindness and confusion. BMJ 2009; 339: b3929.

16. Sejersted OM, Jacobsen D, Ovrebø S, Jansen H. Formate concentrations in plasma from patients poisoned with methanol. Acta Med Scand 1983; 213: 105-110. 